\title{
Hemodiyaliz Hastalarında Hepatit B ve Hepatit C Virus Enfeksiyonlarının Serolojik ve Moleküler Yöntemlerle Araştırılması*
}

\section{Investigation of Hepatitis B and Hepatitis C Virus Infections by Serological and Molecular Methods in Hemodialysis Patients}

\author{
Duygu DAĞLAR ${ }^{1}$, Ayla ERGANi ${ }^{2}$, Hadiye DEMIRBAKAN ${ }^{3}$, Betil ÖZHAK BAYSAN ${ }^{4}$, \\ Gözde ÖNGÜT ${ }^{4}$, Hüseyin KOÇAK ${ }^{5}$, Dilara ÖĞÜNÇ ${ }^{4}$, Halide AKBAŞ ${ }^{6}$, Bülent YILDIRIM ${ }^{7}$, \\ Dilek ÇOLAK ${ }^{4}$
}

\footnotetext{
${ }^{1}$ Antalya Eğitim ve Araştırma Hastanesi, Tıbbi Mikrobiyoloji Laboratuvarı, Antalya.

${ }^{1}$ Antalya Training and Research Hospital, Medical Microbiology Laboratory, Antalya, Turkey.

${ }^{2}$ CNRS, Yapısal ve Moleküler Viroloji Laboratuvarı, Gif-sur-Yvette.

${ }^{2}$ CNRS, Laboratoire de Virologie Moléculaire Et Structurale, Gif-sur-Yvette, France, Turkey.

${ }^{3}$ Gaziantep Şehitkamil Devlet Hastanesi, Tıbbi Mikrobiyoloji Laboratuvarı, Gaziantep.

${ }^{3}$ Gaziantep Sehitkamil State Hospital, Medical Microbiology Laboratory, Gaziantep, Turkey.

${ }^{4}$ Akdeniz Üniversitesi Tıp Fakültesi, Tıbbi Mikrobiyoloji Anabilim Dalı, Antalya.

${ }^{4}$ Akdeniz University Faculty of Medicine, Department of Medical Microbiology, Antalya, Turkey.

${ }^{5}$ Akdeniz Üniversitesi Tıp Fakültesi, iç Hastalıkları Anabilim Dalı, Nefroloji Bilim Dalı, Antalya.

${ }^{5}$ Akdeniz University Faculty of Medicine, Department of Internal Medicine, Nephrology Unit, Antalya, Turkey.

${ }^{6}$ Akdeniz Üniversitesi Tıp Fakültesi, Tıbbi Biyokimya Anabilim Dalı, Antalya.

${ }^{6}$ Akdeniz University Faculty of Medicine, Department of Medical Biochemistry, Antalya, Turkey.

${ }_{7}^{7}$ Akdeniz Üniversitesi Tıp Fakültesi, iç Hastalıkları Anabilim Dalı, Gastroenteroloji Bilim Dalı, Antalya.

${ }^{7}$ Akdeniz University Faculty of Medicine, Department of Internal Medicine, Gastroenterology Unit, Antalya, Turkey.
}

* Bu çalışma Akdeniz Üniversitesi Bilimsel Araştırma Projeleri Koordinasyon Birimi tarafından desteklenmiştir (Proje no: 2005.01.0103.009).

Geliş Tarihi (Received): 18.03.2013 • Kabul Ediliş Tarihi (Accepted): 29.07.2013

\section{ÖZET}

Hemodiyaliz hastalarında hepatit B virus (HBV) ve hepatit C virus (HCV) enfeksiyonları önemli morbidite ve mortalite nedenidir; zira bu hastalar immün süpresif oldukları için enfeksiyonlara karşı duyarlııkları artmıştır. Bu çalışmada, kronik hemodiyaliz hastalarında HBV ve HCV enfeksiyonlarının serolojik ve moleküler yöntemlerle araştıııması ve ayrıca okült HBV enfeksiyonu oranının ve viral genotiplerin belirlenmesi amaçlanmıştır. Retrospektif değerlendirmenin yapıldığı bu çalışmaya, 2006 yılında, Antalya ili içerisinde üç ayrı merkezde hemodiyaliz yapılan toplam 201 son dönem böbrek hastası alınmıştır. Hastaların serum örneklerinde HBV ve HCV belirteçleri ELISA yöntemi ile, plazma örneklerinde viral nükleik asit varlığı ise 
gerçek zamanlı polimeraz zincir reaksiyonu (PCR) ile araştırılmış; viral genotipler DNA dizi analizi yöntemi ile belirlenmiştir. Aşılı olanlar hariç tutularak, en az bir HBV göstergesi (HBsAg, anti-HBc total, HBV DNA) pozitifliği HBV enfeksiyonu; en az bir HCV göstergesi (anti-HCV, HCV RNA) pozitifliği HCV enfeksiyonu ve HBsAg negatif olgularda HBV DNA'nın pozitif olması okült HBV enfeksiyonu olarak kabul edilmiştir. Hastaların 80 (\%40)'i kadın ve 121 (\%60)'i erkek olup, yaş ortalaması $51.16 \pm 16.28$ (aralık 17-93) yıldır. Hemodiyaliz hastalarından 89 (\%44.3)'unda HBV aşılamasına bağlı olarak salt anti-HBs pozitifliği bulunmaktadır. Yüz (\%50) hastada HBV, 40 (\%20) hastada HCV enfeksiyonu tespit edilmiş; 24 (\%12) hastada ise HBV ve HCV koenfeksiyonu saptanmıştır. Seksen beş (\%42.3) hastada HBV ve HCV enfeksiyonu bulunmamıştır. Beş (\%2.5) hastada HBsAg pozitif olup, dördünde HBV DNA da pozitiftir. Ek olarak HBV DNA saptanan 1 (\%0.5) hastada okült HBV enfeksiyonu tanımlanmıştır. Anti-HCV 37 (\%18.4) hastada, HCV RNA 24 (\%12) hastada pozitif bulunmuştur. HCV RNA pozitif olan olgulardan 3 (\%12.5)'ünde anti-HCV negatiftir. HBV DNA pozitif hastaların tümünde (\%100), HCV RNA pozitif 24 olgunun 15 (\%62.5)'inde AST ve ALT düzeyleri normaldir. Tüm HBV izolatları genotip D ve tüm HCV izolatları genotip $1 \mathrm{~b}$ olarak tiplendirilmiştir. HBV enfeksiyonu ile hastaların yaşları, hemodiyaliz süresi ve serum transaminaz yüksekliği arasında anlamlı bir ilişki saptanmamış ( $p>0.05$ ), buna karşın HCV enfeksiyonunun yaşla birlikte arttığı görülmüştür $(p=0.047)$. HCV enfeksiyonu ile hemodiyaliz süresi arasında da istatistiksel olarak anlamlı bir ilişki bulunmuş; $\geq 25$ ay hemodiyalize girenlerde HCV enfeksiyonu riskinin arttığı izlenmiştir $(p<$ 0.001, OR: 0.224, \%95 Cl= 0.089-0.562). HCV enfeksiyonu varlığı (anti-HCV ve/veya HCV RNA pozitif) ile serum transaminaz yüksekliği arasında istatistiksel olarak anlamlı bir ilişki saptanmıştır $(p<0.001)$. Bununla birlikte HCV RNA saptanan anti-HCV negatif üç olgudan ikisinde serum transaminaz düzeyleri normal olup, hastaların viral yükü yüksektir. Bu nedenle hemodiyaliz hastalarında HCV enfeksiyonu takibinde yalnızca anti-HCV ve serum transaminaz düzeylerinin incelenmesi yeterli olmayabilir; bu hastalarda periyodik olarak HCV RNA araştırılması gereklidir. Benzer olarak bir olguda okült HBV enfeksiyonunun tanımlanması, hastalarda periyodik olarak HBV DNA araştırılması gerektiğini düşündürmektedir.

Anahtar sözcükler: Hemodiyaliz; hepatit B; hepatit C; HBV; HCV; okült enfeksiyon; genotip.

\section{ABSTRACT}

Hepatitis B virus (HBV) and hepatitis C virus (HCV) infections are significant causes of morbidity and mortality in hemodialysis patients, since those patients are highly susceptible to infections due to immune suppression. The aims of this study were to investigate the presence of HBV and HCV infections in chronic hemodialysis patients by serological and molecular methods, and to determine the rate of occult HBV infection and the viral genotypes. A total of 201 patients who were under hemodialysis due to end-stage renal disease, were retrospectively evaluated. The study involved the patients at three different centers in Antalya, Turkey during 2006. HBV and HCV markers in the patients' sera were screened by ELISA method, viral nucleic acids were investigated by real-time polymerase chain reaction (PCR) in patients' plasma and viral genotypes were determined by DNA sequence analysis. Detection of at least one of the HBV markers HBsAg, anti-HBc total, and HBV DNA, was accepted as HBV infection, and detection of anti-HCV and/or HCV RNA was accepted as HCV infection. HBsAg positive patients with negative HBV DNA were considered as occult HBV infection. Of the patients 80 (40\%) were female, 121 (60\%) were male and the mean age was $51.16 \pm 16.28$ (range 17-93) years. In our study, sole anti-HBs positivity due to HBV vaccination, was detected in 89 (44.3\%) patients. One hundred (50\%) patients were found positive in terms of HBV infection and 40 (20\%) were positive for HCV infection, while 24 (12\%) patients had HBV and HCV co-infections. Eighty-five (42.3\%) patients had no HBV and HCV infection. Among the 5 (2.5\%) patients who were HBsAg positive, four were also HBV DNA positive. Occult HBV infection was detected in 1 (0.5\%) patient. Anti-HCV and HCV RNA were found positive in 37 (18.4\%) and in 24 (12\%) patients, respectively. Among the HCV-RNA positive patients, 3 (12.5\%) were anti-HCV negative. ALT and AST levels were found normal in all of the HBV DNA positive patients, and $62.5 \%$ $(15 / 24)$ of HCV RNA positive patients. All of the HBV isolates were identifed as genotype D and HCV isolates as genotype $1 \mathrm{~b}$. No statistically significant correlation was detected between the HBV infection 
and patients' age, duration of hemodialysis and elevation of serum transaminase levels $(p>0.05)$. On the other hand, HCV infection was seen to increase with age ( $p=0.047)$. HCV infection showed a statistically significant increase with the duration of hemodialysis. HCV infection risk was increased in patients who were under hemodialysis for $\geq 25$ months ( $p<0.001$, OR: $0224,95 \% \mathrm{Cl}=0089-0562$ ). There was also a statistically significant correlation between the presence of HCV infection (anti-HCV and/or HCV RNA positive) and high levels of serum transaminases $(p<0.001)$. However, in two of the three cases who were anti-HCV negative and HCV RNA positive, serum transaminase levels were normal while the viral loads were high. Therefore to follow-up HCV infection in the hemodialysis patients, anti-HCV and serum transaminase levels may not be sufficient alone and these patients should be evaluated periodically for HCV RNA. In addition, the detection of occult HBV infection in one of the study patients, indicated that HBV DNA should also be investigated at regular intervals in the hemodialysis patients.

Key words: Hemodialysis; hepatitis $B$; hepatitis $C$; HBV; HCV; occult infection; genotype.

\section{Giriş̧}

Hemodiyaliz (HD) hastaları, kronik böbrek yetmezliği nedeniyle immün süpresif oldukları için enfeksiyonlara karşı duyarlılıkları artmıştır ${ }^{1}$. Bu olgular, özellikle kan yoluyla bulaşan enfeksiyonlar açısından yüksek risk altındadırlar ve bu yolla bulaşan hepatit B ve hepatit C viruslarına (sırasıyla HBV ve HCV) bağlı karaciğer hastalıkları, önemli mortalite ve morbiditeye neden olmaktadır ${ }^{1,2}$. Hemodiyaliz hastalarında gelişen immün süpresyon nedeniyle, HBV ve HCV enfeksiyonlarının tanısında antijen ve antikor tayinine yönelik testlerin yanında, moleküler yöntemlerle HBV DNA ve HCV RNA'nın da araştırılması gerektiği belirtilmektedir ${ }^{3}$. Ayrıca, bu hastalarda okült (gizli) HBV enfeksiyonu da reaktivasyonla sonuçlanabilir ve potansiyel bulaş yolu olduğu için önemlidir ${ }^{4}$. Alınan tüm önlemlere karşın, HD hastalarında nozokomiyal HBV ve HCV enfeksiyonlarının gelişebileceği de bildirilmektedir ${ }^{5}$. Bu çalışmada, kronik HD hastalarında HBV ve HCV enfeksiyonlarının serolojik ve moleküler yöntemlerle araştırılması, ayrıca okült HBV enfeksiyonu oranının ve viral genotiplerin belirlenmesi amaçlanmıştır.

\section{GEREÇ ve YÖNTEM}

Akdeniz Üniversitesi Tıp Fakültesi Etik Kurulu tarafından onaylanan bu çalışmada, 2006 yılına ait veriler retrospektif olarak değerlendirildi. Çalışmaya, Antalya ili içerisinde, üç ayrı merkezde HD yapılan toplam 201 son dönem böbrek hastası dahil edildi. Olguların aydınlatılmış onamları alındıktan sonra, HBV aşı bilgisi kaydedildi ve alınan kan örnekleri uygun koşullarda laboratuvara ulaştırıldı.

Serumlarda HBsAg, anti-HBs, anti-HBc total ve anti-HCV varlığı ELıSA yöntemi (Roche Modular Analytics E170 Assay, Almanya ve Abbott AxSYM, ABD) ile üretici firmaların önerileri doğrultusunda araştırıldı. HBV DNA ve HCV RNA varlığı, BioRobot EZ1 System (Qiagen, ABD) ile EZ1 Virus Mini Kit (Qiagen, ABD) kullanılarak üretici firmanın önerileri doğrultusunda, plazma örneklerinden ekstrakte edildi ve ardından HBV DNA (RealArt HBV RG RT PCR, Qiagen, Almanya) ve HCV RNA (RealArt HCV RG RT PCR, Qiagen, Almanya) gerçek zamanlı polimeraz zincir reaksiyonu (PCR) ile (RotorGene 3000, 
Corbett Research, Avustralya) üretici firmanın önerileri doğrultusunda çalışıldı. Üretici firma tarafından, HBV DNA kitinin analitik duyarlılı̆ı $3.8 \mathrm{IU} / \mathrm{ml}$, linearitesi $1.1->4 \mathrm{x}$ $10^{9} \mathrm{IU} / \mathrm{ml}$; HCV RNA kitinin ise analitik duyarlılığı $34 \mathrm{IU} / \mathrm{ml}$, linearitesi $65-1 \times 10^{6} \mathrm{IU} /$ $\mathrm{ml}$ arasında verilmektedir.

HBV DNA pozitif olguların PCR ürünlerine, genotipin belirlenmesi amacıyla, pre-S gen bölgesi için DNA dizi analizi (Beckman Coulter DNA Sequencer, ABD) uygulandı; belirlenen diziler aynı bölge için yayımlanan GenBank (http://www.ncbi.nlm.nih.gov/ genbank/) verileri ile karşılaştırıldı. HCV genotiplendirmesi için NS5B, E1 ve 5'UTR bölgelerine yönelik primerler kullanılarak yapılan PCR sonrası elde edilen ürünlere dizi analizi (ABI 3100 Genetic Analyzer, Perkin-Elmer Applied Biosciences, ABD) uygulandı ve veriler MEGA 4.0.2 programı kullanılarak incelendi. Hasta serumlarında AST ve ALT düzeyleri spektrofotometrik yöntemle (Roche Modular System, Almanya) kantitatif olarak saptandı.

Aşılı olanlar hariç tutularak en az bir HBV göstergesi ( $\mathrm{HBsAg}$, anti-HBc total, HBV DNA) pozitifliği HBV enfeksiyonu; en az bir HCV göstergesi (anti-HCV, HCV RNA) pozitifliği HCV enfeksiyonu; HBsAg negatif olgularda HBV DNA pozitifliği ise okült HBV enfeksiyonu olarak kabul edildi ${ }^{6}$.

Verilerin istatistiksel analizinde SPSS 18.0 programı kullanıldı. Veriler arasında karşılaştırma yaparken Mann-Whitney U, Pearson ki-kare ve Fisher's exact testleri; risk analizi için ise Pearson ki-kare testlerinden yararlanıldı. $p$ değeri $<0.05$ olan sonuçlar anlamlı kabul edildi.

\section{BULGULAR}

Çalışmaya alınan 201 olgunun 80 (\%40)'i kadın, 121 (\%60)'i erkek olup, yaş ortalaması $51.16 \pm 16.28$ (aralık 17-93) yıl olarak hesaplanmıştır. Hastaların 89'unda (\%44.3) HBV aşılamasına bağlı olarak salt anti-HBs pozitifliği bulunmaktadır. Yüz (\%50) olguda HBV, 40 (\%20) olguda HCV enfeksiyonu saptanmış; 24 (\%12) olguda ise HBV ve HCV koenfeksiyonu belirlenmiştir. Serum transaminaz düzeylerine göre belirlenen 26 serolojik profil grubu Tablo I'de gösterilmiştir.

HBsAg pozitif bulunan 5 (\%2.5) hastanın tümünde serum transaminaz düzeyleri normal olup, 4'ünde HBV DNA pozitifliği saptanmıştır (Tablo I). Diğer taraftan HBV DNA varlığı saptanan 5 (\%2.5) hastanın 2'sinde çok düşük düzeyde pozitiflik izlenmiş (sırasıyla 1 ve $2 \mathrm{IU} / \mathrm{ml}$ ), ilkinde salt anti-HBc pozitifliği belirlenerek okült HBV enfeksiyonu (\%0.5) olarak değerlendirilmiş, ikincisinde ise $\mathrm{HBsAg}$, anti-HBs ve anti-HBc pozitif olarak saptanmıştır. Plazma HBV DNA düzeyi $7.8 \times 10^{8} \mathrm{IU} / \mathrm{ml}, 3.7 \times 10^{8} \mathrm{IU} / \mathrm{ml}$ ve $1.6 \times 10^{4} \mathrm{IU} /$ ml olan, sırasıyla üçüncü, dördüncü ve beşinci hastalarda $\mathrm{HBsAg}$ ve anti-HBc pozitiftir.

Anti-HCV, 37 (\%18.4) hastada pozitif bulunmuştur. HCV RNA saptanan 24 (\%12) hastanın 3 (\%12.5)'ünde anti-HCV negatif olup, viral yük $2.1 \times 10^{3} \mathrm{IU} / \mathrm{ml}, 2.4 \times 10^{3} \mathrm{IU} /$ $\mathrm{ml}$ ve $1.2 \times 10^{6} \mathrm{IU} / \mathrm{ml}$ olarak saptanmıştır. 


\begin{tabular}{|c|c|c|c|c|c|c|c|}
\hline $\begin{array}{l}\text { Transaminaz } \\
\text { düzeyleri }\end{array}$ & Sayı & Anti-HBs & HBsAg & Anti-HBc & HBV DNA & Anti-HCV & HCV RNA \\
\hline \multicolumn{8}{|l|}{ Normal } \\
\hline Grup 1 & 12 & - & - & - & - & - & - \\
\hline Grup 2 & 69 & + & - & - & - & - & - \\
\hline Grup 3 & 62 & + & - & + & - & - & - \\
\hline Grup 4 & 5 & - & - & + & - & - & - \\
\hline Grup 5 & 1 & + & + & - & - & - & - \\
\hline Grup 6 & 1 & + & + & + & + & - & - \\
\hline Grup 7 & 1 & - & + & + & + & - & - \\
\hline Grup 8 & 1 & - & - & + & + & - & - \\
\hline Grup 9 & 9 & + & - & + & - & + & - \\
\hline Grup 10 & 1 & + & - & + & - & - & + \\
\hline Grup 11 & 5 & + & - & + & - & + & + \\
\hline Grup 12 & 1 & + & - & + & - & + & + \\
\hline Grup 13 & 1 & + & - & - & - & - & + \\
\hline Grup 14 & 3 & + & - & - & - & + & - \\
\hline Grup 15 & 4 & + & - & - & - & + & + \\
\hline Grup 16 & 1 & - & - & + & - & + & + \\
\hline Grup 17 & 1 & - & + & + & + & + & + \\
\hline Grup 18 & 1 & - & + & + & + & + & - \\
\hline \multicolumn{8}{|l|}{ Yüksek } \\
\hline Grup 19 & 4 & + & - & - & - & - & - \\
\hline Grup 20 & 4 & + & - & + & - & - & - \\
\hline Grup 21 & 3 & + & - & + & - & + & + \\
\hline Grup 22 & 6 & + & - & - & - & + & + \\
\hline Grup 23 & 1 & + & - & - & - & - & + \\
\hline Grup 24 & 1 & - & - & + & - & - & - \\
\hline Grup 25 & 1 & + & - & - & - & + & - \\
\hline Grup 26 & 2 & + & - & + & - & + & - \\
\hline
\end{tabular}

HBV DNA pozitif hastaların tümünde (\%100), HCV RNA pozitif 24 olgunun 15 (\%62.5)'inde AST ve ALT düzeyleri normaldir.

HBV enfeksiyonu ile hastaların yaşları, HD süresi ve serum transaminaz yüksekliği arasında istatistiksel bir ilişki bulunmamıştır (sırasıyla; $p=0.320, p=0.790$ ve $p=0.669$ ). 
HCV enfeksiyonunun ise yaşla birlikte arttığı $(p=0.047)$ ve HD süresiyle istatistiksel olarak anlamlı bir ilişki gösterdiği belirlenmiştir $(p<0.001)$. HCV enfeksiyonu riskinin, $\geq 25$ ay hemodiyalize girenlerde daha yüksek olduğu izlenmiştir ( $p<0.001$, OR: 0.224, \%95 Cl= 0.089-0.562). Hem anti-HCV hem de HCV RNA varlığı ile serum transaminaz yüksekliği arasında istatistiksel olarak anlamlı bir ilişki saptanmıştır $(p<0.001)$.

Genotiplendirme sonucunda, HBV izolatları genotip D, HCV izolatları ise genotip $1 \mathrm{~b}$ olarak tiplendirilmiştir.

\section{TARTIŞMA}

Bu çalışmada, hemodiyaliz (HD) hastalarında HBV ve HCV enfeksiyonlarının görülme sıklığı sırasıyla \%50 ve \%20 olarak saptanmış; HBsAg pozitifliği \%2.5, HBV DNA pozitifliği \%2.5, anti-HCV pozitifliği \%18.4, HCV RNA pozitifliği ise \%12 olarak belirlenmiştir. HBV izolatlarının tümü genotip D, HCV izolatlarının tümü de genotip $1 \mathrm{~b}$ olarak bulunmuş, bu sonuçların ülkemizin genotip profili ile uyumlu olduğu izlenmiştir ${ }^{7,8}$. Kaygusuz ve arkadaşlarının ${ }^{9}$ çalışmasında, 20.000'den fazla HD hastasında anti-HCV pozitifliği \%23.9 olarak bildirilmiş; Türk Nefroloji Derneği (TND) kayıtlarına göre de Türkiye genelinde HD hastalarında anti-HCV pozitifliği 1997 yılında \%54.6, 2006 yılında \%15.9 ve 2011 yılında \%7.9 olarak rapor edilmiştir ${ }^{10,11}$. Akdeniz Üniversitesi Hastanesinde, 1997 yılında, HD hastalarında anti-HCV prevalansı, ikinci jenerasyon ELISA testi ile \%62.7 olarak bulunmuştur ${ }^{12}$. Çalışmamızda saptanan \%18.4'lük oran, TND'nin, 2006 yılı için bildirdiği sonuç ile benzerdir. Bununla birlikte, çalışma grubumuzu oluşturan üç merkezden biri olan hastanemiz HD ünitesinde, 2011 yılında anti-HCV pozitifliği \%5.3 olarak saptanmıştır (yayınlanmamış bulgu). Aradan geçen süre içinde izolasyon ve dezenfeksiyon önlemlerinin daha etkin uygulanması ve anti-HCV ELISA testlerinde duyarlılık ve özgüllüğü artırılmış ileri jenerasyon testlerin kullanılması, aradaki farkı açıklayabilir. Benzer olarak, Selçuk Üniversitesi Tıp Fakültesi Hemodiyaliz Ünitesi'nde 1990 yılında \%48 olan anti-HCV pozitifliğinin 2000 yılında \%19.1'e düştüğü bildirilmektedir ${ }^{13}$. Araştırmacılar bunu anti-HCV pozitif makinelerin ayrılması, eritropoetin uygulamasıyla kan transfüzyon ihtiyacının azalması, enfeksiyon kontrol kurallarına sıkı uyum ve üçüncü jenerasyon testlerin kullanımına bağlamaktadırlar.

Hemodiyaliz hastalarında HCV takibinde, serumda ELISA ile anti-HCV araştırılmakta, pozitif sonuç alındığında moleküler yöntemlerle HCV RNA varlığı ve miktarı değerlendirilmektedir. HD hastalarında HCV RNA ve anti-HCV pozitifliği her zaman birlikte değildir. Bozdayı ve arkadaşları ${ }^{14} 2002$ yılında HD hastalarında anti-HCV prevalansını \%43.6 olarak bulmuşlar; anti-HCV negatif üç olguda HCV RNA pozitifliği bildirerek, anti-HCV ve HCV RNA'nın birlikte çalışılmasını önermişlerdir. Çalışmamızda HCV enfeksiyonunun; yaş, HD süresi ve serum transaminaz yüksekliği ile ilişkili olduğu bulunmuş; iki yıldan uzun HD uygulamasının, HCV enfeksiyonu riskini artırdığı belirlenmiştir. Bu bulgu başka çalışmalarla da desteklenmektedir ${ }^{15}$. Kronik HCV enfeksiyonu olan HD hastalarında transaminaz düzeyleri normal olabilir ${ }^{1}$. Anti-HCV pozitif, HCV RNA negatif olan hastalarda 
bu durum geçirilmiş HCV enfeksiyonuna bağlı olabileceği gibi, kronik HCV enfeksiyonu nedeniyle de oluşabilir. Çalışmamızda HCV RNA saptanan anti-HCV negatif üç olgudan ikisinde transaminaz düzeyleri normal olmakla birlikte viral yük yüksektir. Bu nedenle HD hastalarında HCV enfeksiyonu takibinde belirli aralıklarla HCV RNA araştırılmalıdır.

Türkiye genelinde HD hastalarında HBsAg pozitifliği, TND kayıtlarına göre 1997 yılında \%11.1, 2006 yılında \%6.8 ve 2011 yılında \%4.3'tür ${ }^{10,11}$. Ülkemizde yapılan çalışmalarda ${ }^{9,16} \mathrm{HD}$ hastalarında HBsAg pozitifliği yaklaşık \%8 oranında bildirilirken, yurt dışı çalışmalarda ${ }^{15,17,18} \%$ 1.4-4.5 olarak rapor edilmektedir. Bizim çalışmamızda HBsAg pozitifliği, TND’nin 2006 yılında bildirdiği orandan daha düşük (\%2.5) saptanmış; ünitemizde 2011 yılında bu oran \%1.3 olarak tespit edilmiştir (yayınlanmamış bulgu). Çalışmamızda HBV enfeksiyonunun yaş ve HD süresi ile anlamlı bir ilişkisi bulunmamıştır. Burada ilk akla gelen HBV aşı uygulamasının etkinliği ve enfeksiyon kontrol önlemleridir. Yapılan çalışmalarda bizim bulgumuzla benzer olarak HD hastalarında HBV enfeksiyonu ile serum transaminaz değerleri arasında net bir ilişki bulunamamıştır ${ }^{1}$.

Okült HBV enfeksiyonu tanısında, HBV DNA'sının karaciğer veya kan örneklerinde PCR ile araştırılması altın standart olarak kabul edilmektedir ${ }^{4}$. Invazif bir işlem olan karaciğer biyopsisi tüm olgulara uygulanamadığından, okült HBV enfeksiyonu ile ilgili veriler genellikle serolojik araştırmalardan elde edilmektedir. Çalışma grupları ve testlerin duyarlılıklarındaki farklııılar nedeniyle ülkemizde ve yurtdışında farklı prevalans oranları söz konusudur ${ }^{19-23}$.

Sonuç olarak, kronik HD hastalarında HBV ve HCV enfeksiyonlarının moleküler yöntemlerle araştırılması, rutin testlerle negatif bulunan olguların saptanmasında temel öneme sahiptir. Bu hastalarda HBV ve HCV enfeksiyonlarının seyri ve epidemiyolojisi hakkında değişen bilgilere ulaşmak açısından, farklı yıllara ait verilerin sunulması yararlı olacaktır.

\section{KAYNAKLAR}

1. Centers for Disease Control and Prevention. Recommendations for preventing transmission of infections among chronic hemodialysis patients. MMWR Recomm Rep 2001; 50(RR-5): 1-43.

2. Ruhi Ç, Süleymanlar $\mathrm{i}$, Koçak $\mathrm{H}$, et al. The impact of hepatitis $\mathrm{C}$ virus infection on long-term outcome in renal transplant patients. Turk J Gastroenterol 2011; 22(2): 165-170.

3. Oesterreicher $\mathrm{C}$, Hammer J, Koch U, et al. HBV and HCV genome in peripheral blood mononucleer blood cells in patients undergoing chronic hemodialysis. Kidney Int 1995; 48(6): 1967-71.

4. Raimondo G, Pollicino T, Cacciola I, Squadrito G. Occult hepatitis B virus infection. J Hepatol 2007; 46(1): 160-70.

5. Aygen B. Hemodiyaliz ünitelerinde hastane infeksiyonu kontrolü. Hastane İnfeksiyonları Dergisi 2006; 10(1): 52-62.

6. Aghakhani A, Banifazl M, Velayati AA, Eslamifar A, Ramezani A. Occult hepatitis B virus infection in hemodialysis patients: a concept for consideration. Ther Apher Dial 2012; 16(4): 328-33.

7. Abacıoğlu YH, Davidson F, Tuncer $S$, et al. The distribution of hepatitis $C$ virus genotypes in Turkish patients. J Viral Hepat 1995; 2(6): 297-301. 
8. Bozdayi AM, Aslan N, Bozdayi G, et al. Molecular epidemiology of hepatitis B, C and D viruses in Turkish patients. Arch Virol 2004; 149(11): 2115-29.

9. Kaygusuz S. Kronik böbrek yetmezliği ve viral hepatitler. Klimik Derg 2004; 17(2): 72-81.

10. Erek E, Süleymanlar G, Serdengeçti K, Altıparmak MR, Sifil A, Seyahi N. Türkiye 2006 yılı Ulusal Hemodiyaliz, Transplantasyon ve Nefroloji Kayıt Sistemi Raporu. Türk Nefroloji Derneği Yayınları. 2007, Pasifik Reklam ve Tanıtım Hizmetleri, İstanbul.

11. Süleymanlar G, Altıparmak MR, Seyahi N, Trabulus S. Türkiye 2011 yılı Ulusal Hemodiyaliz, Transplantasyon ve Nefroloji Kayıt Sistemi Raporu. Türk Nefroloji Derneği Yayınları. 2012, Pasifik Reklam ve Tanıtım Hizmetleri, İstanbul.

12. Süleymanlar G, Süleymanlar i, Sezer T ve ark. Hemodiyaliz veya sürekli ayaktan periton diyalizi uygulanan kronik böbrek yetmezliği hastalarında hepatit C virus enfeksiyonu: karşılaştırmalı analiz sonuçları. Turk J Gastroenterol 1997; 8(1): 21-7.

13. Altıntepe $L$, Türk $S$, Tonbul $Z$ ve ark. Hemodiyaliz ünitemizde son 10 yılda değişen anti-hepatit $C$ virüs (HCV) prevalansı. Turk Neph Dial Transpl 2000; 9(3): 138-42.

14. Bozdayı G, Rota S, Verdi H ve ark. Hemodiyaliz hastalarında hepatit C virus (HCV) enfeksiyon varlığının araştırılması ve HCV genotip dağılımının belirlenmesi. Mikrobiyol Bul 2002; 36(3-4): 291-300.

15. Gasim GI, Hamdan HZ, Hamdan SZ, Adam I. Epidemiology of hepatitis B and hepatitis C virus infections among hemodialysis patients in Khartoum, Sudan. J Med Virol 2012; 84(1): 52-5.

16. Sırmatel F, Sırmatel Ö, Usalan C ve ark. Hemodiyaliz hastalarında viral hepatit B ve $C$ seroprevalansı. İnfeksiyon Derg 2008; 22(1): 23-8.

17. Joukar F, Besharati S, Mirpour H, Mansour-Ghanaei F. Hepatitis C and hepatitis B seroprevalence and associated risk factors in hemodialysis in Guilan province, North of Iran: HCV and HBV seroprevalence in hemodialysis patients. Hepat Mon 2011; 11(3): 178-81.

18. Alavian SM, Bagheri-Lankarani K, Mahdavi-Mazdeh M, Nourozi S. Hepatitis B and C in dialysis units in Iran: changing the epidemiology. Hemodial Int 2008; 12(3): 378-82.

19. Di Stefano M, Volpe A, Stallone G, et al. Occult HBV infection in hemodialysis setting is marked by presence of isolated antibodies to HBCAg and HCV. J Nephrol 2009; 22(3): 381-6.

20. Mina P, Georgiadou SP, Rizos C, Dalekos GN, Rigopoulou El. Prevalence of occult hepatitis B virus infection in haemodialysis patients from central Greece. World J Gastroenterol 2010; 16(2): 225-31.

21. Keyvani H, Agah S, Kabir A, Alavian SM. Prevalence and risk factors of isolated anti-HBc antibody and occult hepatitis B infection in hemodialysis patients: a nationwide study. Ann Hepatol 2013; 12(2): 213-9.

22. Goral V, Ozkul H, Tekes S, Sit D, Kadiroglu AK. Prevalence of occult HBV infection in haemodialysis patients with chronic HCV. World J Gastroenterol 2006; 12(21): 3420-4.

23. Sav T, Gursoy S, Torun E, Sav NM, Unal A, Oymak O, Utas C. Occult HBV infection in continuous ambulatory peritoneal dialysis and hemodialysis patients. Ren Fail 2010; 32(1): 74-7. 